\title{
Human and Regional Geography of Zambia
}

Dr. George KaY, formerly a Research Officer of the Rhodes-Livingstone Institute and now Lecturer in Geography at Hull University, is engaged in a study of the human and regional geography of Zambia. Work in progress includes a geographical analysis of population data for the whole country and for selected towns (Lusaka and Nkana-Kitwe), and the preparation of an advanced textbook provisionally entitled 'A Population Geography of Zambia'.

\section{Urbanization in Africa: Centre of Documentation and Research}

A CENTRE of Documentation and Research on Urbanization in Africa South of the Sahara has recently been established, under the direction of Professor Paul Mercier, at the École Pratique des Hautes Études (VIth Section, Economic and Social Sciences), 20, rue de la Baume, Paris VIIIe. The Centre's first concern will be documentation: analysis of books and articles, collection of unpublished reports, etc. The publication of annotated bibliographies will begin in 1966, each one being devoted to a particular aspect of African urban problems. The Centre has sent out a questionnaire with a view to collecting pre-publication information on research in progress, recently completed, or planned, in ethnology, sociology, demography, and economics. Such information will be recorded in a card index and will be available to all interested research workers.

\section{The African Research and Information Center, Washington, D.C.}

The African Research and Information Center (AFRIC), at 1622 2ist Street N.W., Washington, D.C. 20009, offers a series of publications, mainly dealing with the Catholic Church in Africa. AFRIC also supplies information on other pamphlets and books on this theme.

\section{Visit of German Nutrition Team to Kenya}

A Nutrition Team from the Federal Republic of Germany, headed by Dr. H. D. Cremer, Professor of Nutrition in the Medical Faculty of Giessen University, and composed of university and research institute staff in the fields of nutrition, food chemistry, botany, agronomy, sociology, economics, and domestic science, visited Kenya from 3 March to 6 April. The team interviewed specialists and others, inspected institutions and projects, and carried out field studies in three selected localities. The team found that the customary diet was generally adequate for the nutritional needs of the people as long as it was not upset by exceptional conditions. Among the recommendations made by the team were the encouragment of cash crops, an advertising campaign, and nutrition education in schools; it was also suggested that projects of nutritional importance might be considered within the framework of Technical Co-operation between the Federal Republic of Germany and Kenya.

\section{Museum of Primitive Art, New York: Radiocarbon Tests on African Carvings}

THE Museum of Primitive Art in New York is at present trying to establish the age of certain African wood carvings by means of the Carbon-I4 method. The sculptures in question have been collected among the Dogon, but are said to be from an earlier people, the Tellem, whom the Dogon encountered when they settled in their present territory of the Bandiagara 